\title{
Antifungal Activity of Melaleuca Essential Oil Against Lasiodiplodia theobromae in Maize Seeds
}

\author{
Ionaly Gomes de Araújo ${ }^{1}$, Kevison Romulo da Silva Franca ${ }^{1 *}$, Flavia Mota de Figueredo \\ Alves $^{1}$, Alda Leaby dos Santos Xavier ${ }^{1}$, Tiago Silva Lima ${ }^{1}$, Lídia Pinheiro da Nóbrega ${ }^{1}$, \\ Antônio Francisco de Mendonça Júnior ${ }^{2}$, Ana Paula Medeiros dos Santos Rodrigues ${ }^{3}$ \\ and Tiago Augusto Lima Cardoso ${ }^{4}$
}

\author{
${ }^{1}$ Agroindustrial Systems, Federal University of Campina Grande, Pombal, PB, Brazil \\ ${ }^{2}$ Department of Agronomy, Rural Federal University of Pernambuco, Recife, PE, Brazil \\ ${ }^{3}$ Agronomy/Plant Protection, Rural Federal University of Semiarid, Mossoró, RN, Brazil \\ ${ }^{4}$ Phytopathology Laboratory, Federal University of Campina Grande, Pombal, PB, Brazil
}

*Corresponding author

\section{A B S T R A C T}

\section{Keywords}

Antimicrobial activity, Mycelial growth, Black rot, Zea mays

\section{Article Info}

Accepted:

15 July 2019

Available Online:

10 August 2019
The fungus Lasiodiplodia theobromae causes black rot in maize seeds, leading to losses in crops production. The fungicides used in the control of black rot are highly toxic, requiring the development of less harmful control techniques. This work evaluates the effect of Melaleuca essential oil against $L$. theobromae, both under in vitro conditions and on maize seeds. The in vitro experiment compared the growth of the fungus in PDA culture medium containing the oil at $0.25,0.50,075$, and $1.0 \%$, a negative control, and positive control (Thiram fungicide). The in vivo experiment analyzed the incidence of $L$. theobromae in maize seeds treated with the essential oil at $0.50,0.75$, and $1.00 \%$, and in the negative and positive controls. After the treatments of seeds, we inoculated them with the fungus and performed sanity tests. In the in vitro test, Melaleuca essential oil inhibited $100 \%$ of mycelial growth in the $0.75 \%$ concentration. In the in vivo test, the oil at $1.0 \%$ concentration reduced the incidence of fungus in the seeds to $45 \%$, being more effective than the synthetic fungicide. Thus, Melaleuca oil has a strong potential as a control agent against fungus $L$. theobromae in maize seeds.

\section{Introduction}

Brazil is the third-largest producer of maize (Zea mays L.) in the world. The 2016/2017 crop covered a cultivated area of 17.6 million hectares (USDA, 2017). The sum of the productivity of the first and second national crop reached 97.8 million tons and obtained an average production of 5.6 tons per hectare
(Conab, 2018). Although highly productive, maize crops are susceptible to several pathogens, and fungi are the microorganisms that promote the most severe losses in production (Barboza, 2015; Fancelli and DouradoNeto, 2008). Grain losses in Brazil comprise $10 \%$ of the harvest, resulting from factors such as climate and diseases, as well as machine regulation errors or limitations of 
manual harvesting. In the post-harvest phase, losses occur due to improper storage, reducing the quantity and quality of stocked products (IBGE, 2005).

Countless fungal species attack maize seeds, damaging plant establishment, weakening seedlings, and decreasing population. The occurrence of pathologies impairs grain yield, quality, palatability, and nutritional value (Pinto, 1998; Wordell Filho and Casa, 2010). For example, the fungus Lasiodiplodia theobromae causes black rot in maize seeds. Symptoms begin with punctate discoloration in the ear top grains, which then turn brown and finally black and dry, presenting a dry rot (Embrapa, 1980; Oliveira et al., 2013; Ma et al., 2016).

Traditionally, producers control black rot using commercial fungicides based on Carboxanilide (Carboxin), Dimethylditiocarbamate (Tiram) and Ethylene Glycol. However, the long-term use of these pesticides harms human health and the environment due to toxicity and pollution caused by chemical wastes. Besides, new control agents become necessary over time due to the selection and multiplication of resistant microorganisms (MAPA, 2009; Silva et al., 2013; Araújo et al., 2017; Miranda et al., 2017).

The problems with synthetic fungicides motivate the search for less harmful natural products to control phytopathogens. The essential oils, which are plant secondary metabolites, stands out among fungicides produced from plants (Venturoso et al., 2011; Araújo and Costa, 2013).

Essential oils are an affordable option to replace or supplement traditional chemical treatments because they have low toxicity to humans (Nardelli et al., 2009; Vigan, 2010) and high efficiency on in vitro and in vivo control of phytopathogens, including in seed treatment (Médice et al., 2007; Pereira et al., 2008; Rodrigues et al., 2006; Silva and Bastos, 2007).

The essential oil of Melaleuca (Melaleuca alternifolia), also called tea tree oil, has in its composition terpinen-4-ol, which has antifungal, bactericidal, antiviral, antiinflammatory, anesthetic, analgesic, antineoplastic, insecticidal, and antiparasitic properties. Several studies addressing traditional medicine and phytopathogen control report the antimicrobial activity of this oil (Lis-Balchin et al., 2000; Hammer et al., 2003; Caldefie-Chezet et al., 2006; Baldissera et al., 2014; Souza et al., 2015).

Some researches show that the Melaleuca oil has low toxicity in humans and mammals (Mikus et al., 2000; Souza and Fernandes, 2006; Nardelli et al., 2009; Vigan, 2010). The Australian Chemical Component Standardization Committee established that the oil should contain amounts below $15 \%$ of cineol, which is irritating to the skin, and terpenen-4-ol above $30 \%$, to ensure minimal antimicrobial efficacy (Simões et al., 2002).

This study aims to evaluate the effect of Melaleuca oil at various concentrations on the development of $L$. theobromae both under in vitro conditions and on maize seed disinfection. Our results will support the development of oil-based technologies to control several fungal pathologies in maize crop, reducing toxicological risks, and improve production sustainability.

\section{Materials and Methods}

The study was carried out at the Phytopathology Laboratory of the Federal University of Campina Grande - UFCG, at Pombal Campus, Paraíba, from June to December 2018. 
The Lasiodiplodia theobromae strain (CMM 4534) was supplied by the Prof. Maria Menezes Phytopathogenic Fungi Culture Collection of the Federal Rural University of Pernambuco. This phytopathogen was isolated from typical fruit lesions. The fungus was multiplied in the PDA (potato dextrose agar) culture medium and incubated at $27 \pm 2^{\circ} \mathrm{C}$.

Melaleuca (Melaleuca alternifolia) essential oil was purchased from a health food store. The company informed the chemical constituents of the essential oil through technical reports. Terpinen-4-ol (42\%) and Gammaterpinene (22\%) comprised the primary components.

\section{In vitro experiment}

The in vitro experiment comprised a completely randomized design with six treatments in five replications each. Treatments included one positive control (PDA culture medium supplemented with $1 \mathrm{~mL} \mathrm{~L}^{-1}$ of Thiram fungicide), one negative control (no supplementation), and four treatments containing increasing doses of Melaleuca essential oil $(0.25,0.50,0.75$ and $1.0 \%)$. The oil concentrations were adapted from Concha et al., (1998) and Martins et al., (2010) with the objective of testing doses similar to those found in these researches.

We added the oil and fungicide to the sterilized culture medium under aseptic conditions. The media was poured into $75 \times 15 \mathrm{~mm}$ Petri dishes. After solidification, one disc of culture medium $(\varnothing=1 \mathrm{~cm})$ containing seven-day-old fungus was deposited in the center of each plate. Plates were incubated at $27 \pm 2^{\circ} \mathrm{C}$ to stimulate mycelial development. Two perpendicular diameters of each colony were measured daily until one of them reached the plate margins. With the results of the measurements, we calculated the percentage of mycelial growth inhibition (PGI; Bastos, 1997) and the mycelial growth rate index (IMGS; Oliveira, 1991) according to formulas (1) and (2):

$P G I=\frac{[\text { (negativecontrolgrowth }- \text { treatmentgrowth })] \times 100}{\text { negativecontrolgrowth }}$

$I M G S=\sum \frac{\text { currentmycelialgrowth-previousmycelialgrowth }}{\text { numberof daysof incubation }}$

\section{In vivo experiment (maize seeds)}

Five hundred seeds of AG 1051 hybrid maize were disinfected by immersion in $2 \%$ sodium hypochlorite solution for 5 minutes. Afterward, the seeds were washed three times with autoclaved water and dried at room temperature. The in vivo experiment consisted of five treatments with ten repetitions each. Treatments comprised solutions of $100 \mathrm{ml}$ of autoclaved distilled water and the following treatments: Melaleuca oil at concentrations of $0.5 \%, 0.75 \%$, and $1.00 \%$; one positive control (100 $\mathrm{mL} \mathrm{L}^{-1}$ of Thiram fungicide); and one negative control. Each solution received the addition of $100 \mu \mathrm{L}$ of Tween 80 to aid dilution of the products in water. One hundred corn seeds were immersed in each solution for 5 minutes and then dried on germitest paper at room temperature for one hour.

The fungus $L$. theobromae was grown in plates containing PDA culture medium and incubated in a BOD incubator at $27 \pm 2^{\circ} \mathrm{C}$ for eight days. After treatments, seeds were contaminated with fungus by deposition on mycelia, so that all seeds remained in contact with fungal structures for 32 hours. Inoculation technique was adapted from Ramos et al., (2014).

After being treated and inoculated, the seeds were subjected to the sanity test by filter paper method with freezing (Limonard, 1966). A hundred seeds of each treatment were distributed in 10 Petri dishes $(\varnothing=14 \mathrm{~cm})$. Ten 
seeds were placed equidistantly on each plate containing two sheets of filter paper previously moistened with sterile distilled water and incubated at $27 \pm 2^{\circ} \mathrm{C}$. After 24 hours, the plates were transferred to a freezer at $-20^{\circ} \mathrm{C}$ for 24 hours and then to a BOD incubator for a further five days. Finally, the number of fungal colonies was counted in each plate, and the results expressed as percentage of infected seeds.

\section{Statistical analysis}

The effect of oil concentration on fungal growth was analyzed applying regressions in quadratic plateau model for in vitro experimental data and in the quadratic model for in vivo experiment. Differences between the effects of Melaleuca oil and synthetic fungicide on Lasiodiplodia theobromae growth and percentage of infection were compared by the Mann-Whitney test (nonparametric pairwise comparisons) assuming a significance level of $5 \%$. The analyses were performed using the $\mathrm{R}$ Core Team 3.5.1 program.

\section{Results and Discussion}

\section{In vitro experiment}

The Melaleuca essential oil reduced the mycelial growth and growth rate of Lasiodiplodia theobromae at all tested concentrations. Inhibition percentages increased significantly with the oil dosage until reaching the maximum value $(\mathrm{PGI}=$ $100 \%$ ) at 0.75 and $1.0 \%$ (Figure 1A). The mycelial growth rate decreased with increasing oil concentration until reaching the minimum value (IVCM $=0.0 \mathrm{~cm} \mathrm{day}^{-1}$ ) also at 0.75 and $1.0 \%$ (Figure 1B). The inhibition caused by the essential oil at its highest concentrations was similar to the synthetic fungicide. Thus, under in vitro conditions, the essential oil may substitute the commercial synthetic fungicide.
The compound Terpinen-4-ol comprises most of the Melaleuca oil, which also contains other chemical components, such as $\alpha$-terpinene, $\gamma$ terpinene, and 1,8-cineole, which contribute to its potent antifungal activity. The mechanisms of action of this essential oil include lipid peroxidation, inhibition of ergosterol biosynthesis, and increase in reactive oxygen species (ROS). These mechanisms damage and induce membrane loss, interfering on the integrity and physiology of the microorganism and finally leading to cell death (Cox et al., 2000; Carson et al., 2006; Kalagatur et al., 2018).

After achieving complete inhibition, increases in oil concentration kept the values at maximum. For this reason, the quadratic plateau model presented the best fit for the relationship between oil dosage and inhibition percentage (Figure 2). The minimum concentration for total inhibition of $L$. theobromae mycelial growth was $0.75 \%$, but regression analysis estimated that a dose of $0.47 \%$ could also generate complete inhibition.

The inhibition percentages obtained with Melaleuca oil against $L$. theobromae differed from the inhibitions caused in other phytopathogenic fungi. Studies with the fungi Aspergillus niger, Penicillium sp., Macrophomina phaseolina, Sclerotinia sclerotiorum, Alternaria alternata, and Colletotrichum gloeosporioides have shown antifungal oil activity in concentrations ranging from 0.20 to $0.80 \%$ (Concha et al., 1998; Martins et al., 2010; Marinelli et al., 2012; Ramos et al., 2016). These differences may be due to the diversity of defense mechanisms of each fungal species and the selection of fungi resistant to compounds in the oil (Wardle and Parkinson, 1990; Takahashi and Melhem, 2014). As Melaleuca essential oil exerts different fungitoxic activities depending on the studied 
microorganism, it generates different inhibited $L$. theobromae mycelial growth minimum concentrations for each species, (Peixinho et al., 2017a). opening opportunities for further investigated.

The essential oil from other plant species also Citronella (Cymbopogon nardus) oil at $1.0 \%$ significantly inhibited $L$. theobromae. For example, mint oil (Mentha arvensis) at a also inhibited the growth of this fungus by $100 \%$, while clove oil (Syzygium aromaticum) minimum concentration of $0.25 \%$ completely at $1.5 \%$ achieved inhibition of only $35.6 \%$ (Peixinho et al., 2017b).

Fig.1A Inhibition of mycelial growth of Lasiodiplodia theobromae in the different concentrations of Melaleuca essential oil and the control treatments. 1B. Mycelial growth speed of Lasiodiplodia theobromaein the different concentrations of Melaleuca essential oil and the control treatments

$\mathbf{A}$

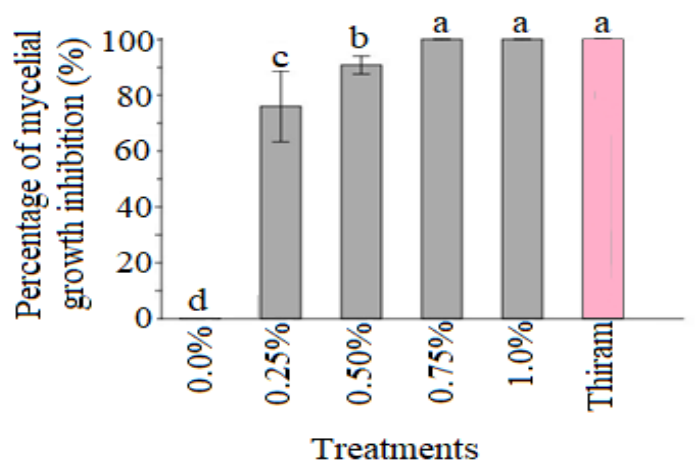

B

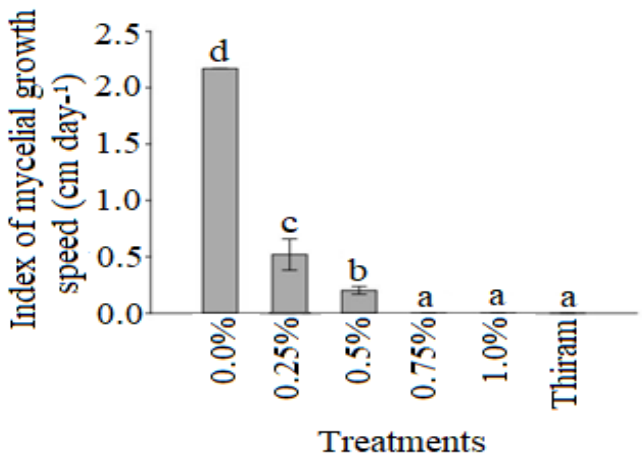

Superscript treatment with the same letter were not significantly different from each other by the Mann-Whitney test $(\mathrm{p}>0.05)$

Fig.2 Effect of different concentrations of Melaleuca essential oil on the mycelial growth of Lasiodiplodia theobromae.The red line shows the direction of effect estimated by plateauquadratic regression

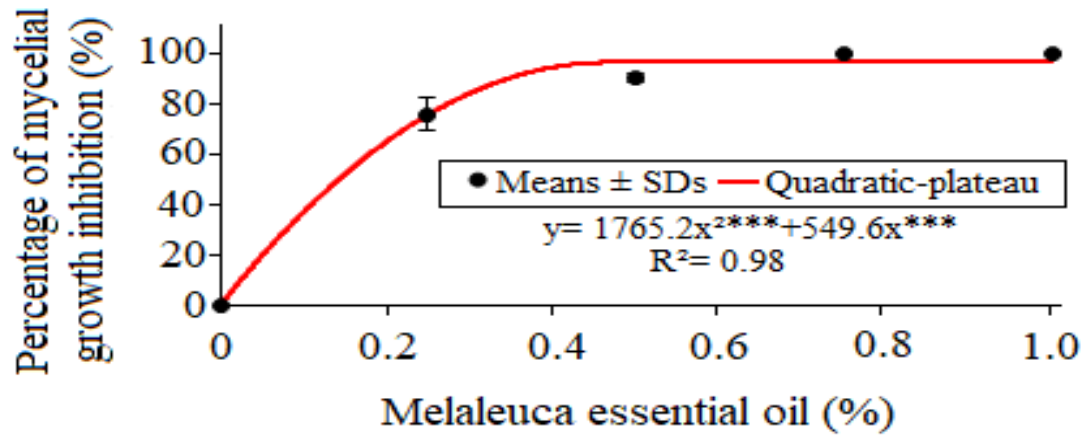

$* * * \mathrm{P}<0.001 ;$ 
Fig.3 Effect of different concentrations of Melaleuca essential oil on the incidence of infected seeds by Lasiodiplodia theobromae

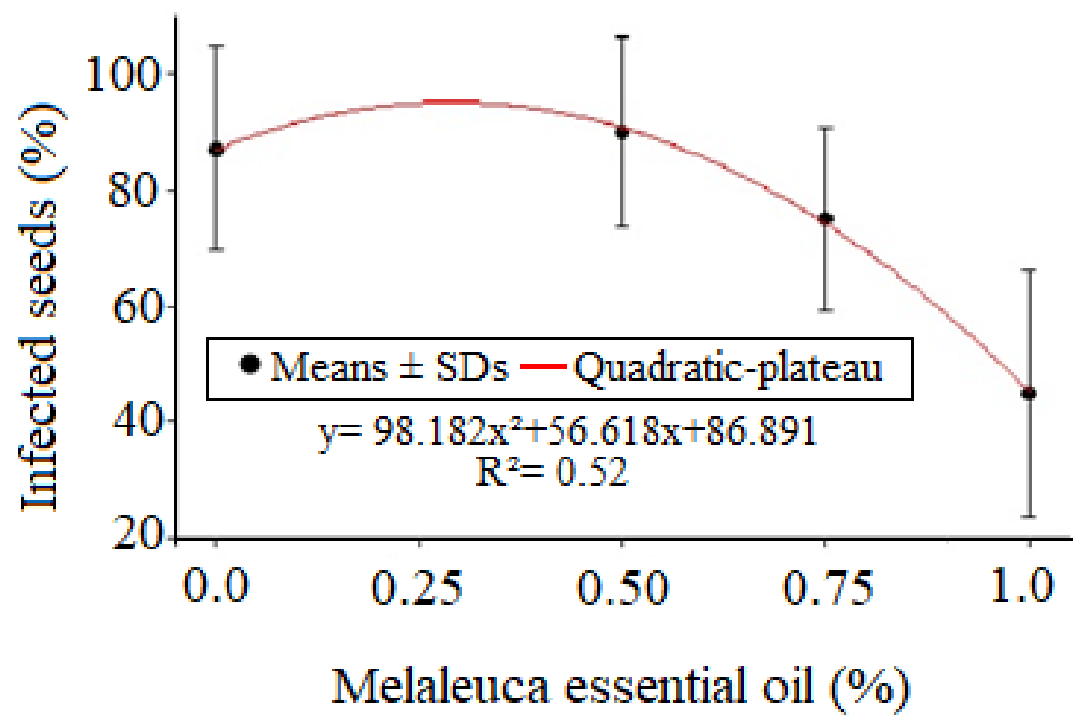

Fig.4 Percentage of infected seed by Lasiodiplodia theobromae after the treatment with the different concentrations of Melaleuca essential oil and the control treatments

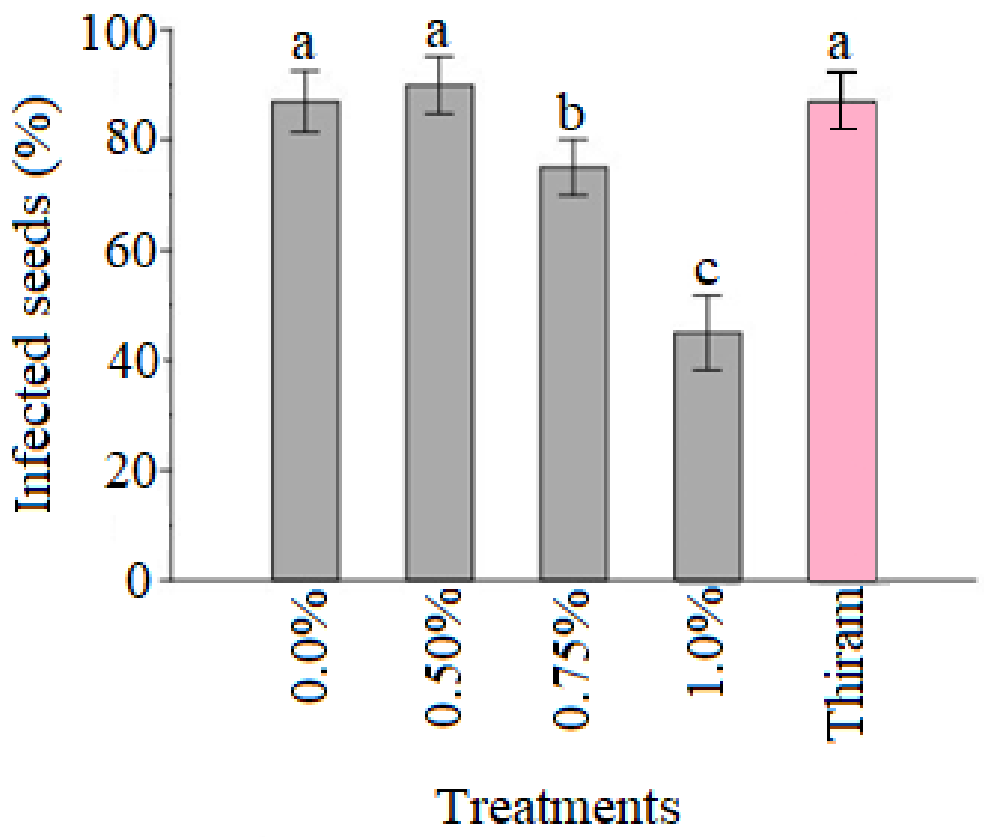

Superscript treatment with the same letter were not significantly different from each other by the Mann-Whitney test $(\mathrm{p}>0.05)$ 
The fungitoxic control promoted by the essential oils occurs through synergism or antagonism between several of its compounds, which act through several mechanisms on several targets at the same time (Hammer et al., 2004; D'Auria et al., 2001; Yu et al., 2015). These characteristics confer advantages over the synthetic fungicide since they hinder the evolution of phytopathogen resistance (Feng and Zheng, 2007).

\section{In vivo experiment (maize seeds)}

The Melaleuca essential oil at 0.75 and $1 \%$ provided a reduction in the incidence of $L$. theobromae in maize seeds, differing significantly from the incidence in untreated seeds (negative control) and treatment with Thiram fungicide (positive control) (Figure 3 and4). None of the concentrations eradicated the pathogen, but the increase in oil concentration decreased the number of colonies (Figure 3). Applying the equation generated by the quadratic polynomial model, we estimated that the minimum dose to eradicate the fungus would be $1.26 \%$.

Thus, our results demonstrate that biologically active compounds in Melaleuca oil promote a significant antifungal effect on L. theobromae mycelial growth under both in vitro and seed treatment conditions. By using the oil at a concentration of $0.75 \%$, we obtained total inhibition of mycelial growth under in vitro conditions. However, seed treatment requires higher doses for effective fungus inhibition (less than $45 \%$ of infected seeds).

The efficiency of tea tree oil on $L$. theobromae observed in our in vivo tests differed from some results previously obtained in the fight against other fungi. For example, the treatment of soybean seeds with Melaleuca oil completely inhibited the incidence of Aspergillus spp. and Phomopsis sp. (Morais et al., 2008). In bell pepper seeds, concentrations of $0.50 \%$ and $0.75 \%$ eradicated the fungus Colletotrichum gloesporioides (Nascimento, 2017). The divergence of the results shows that the effectiveness of the oil varies according to the pathogen species. Fungi mycelial growth rate (IMGS) may be one of the factors that interfere with control efficacy, an issue that deserves further studies (Amponsah et al., 2012; Bester et al., 2007; Rolshausen et al., 2010).

The effect of $1.0 \%$ Melaleuca oil against $L$. theobromae in maize seeds was superior to the effect of Thiram synthetic fungicide, with an average incidence of $45 \%$ in contrast to $87 \%$ of Thiram (Figure 4). Despite the need for a higher oil concentration than the Thiram concentration to reduce the number of infected seeds, the use of a less harmful natural product may be a safer alternative for fungus control.

However, even if it is natural oil, the recommended minimum concentrations should be considered to avoid toxicity to humans and to minimize environmental impacts. We suggest the evaluation of each component of the oil isolated, as the action of different chemical compounds in high dosage may increase the oil toxicity.

Melaleuca essential oil completely inhibited $L$. theobromae growth under in vitro conditions, with a minimum dose of $0.75 \%$. Also, the oil reduced the incidence of black rot in maize seeds, with an optimal effect from the $1 \%$ concentration, presenting greater efficacy than the commercial Thiram fungicide. Our results can be useful in formulating pesticides based on Melaleuca essential oil for use in agroecological crops, minimizing the impacts of synthetic pesticides. 


\section{References}

Amponsah, N.T., Jones, E., Ridgway, H.J., and Jaspers, M.V. (2012). Evaluation of fungicides for the management of Botryosphaeria dieback diseases of grapevines. Pest management science. 68(5): 676-683.

ANVISA - AGÊNCIA NACIONAL DE VIILÂNCIA SANITÁRIA. Informações comuns à espécie vegetal (droga vegetal) Melaleucaalternifolia e a seus derivados. (2016). Acessed: 11 Jan 2018. Avaible:

Araújo, I.C.S., Ferreira, R.L.P.S., Macedo, A.T., Santos, J.C.B., andSantos, J.A.R. (2017). Resistência cruzada entre agrotóxicos e antifúngicos de uso clínico contra Cryptococcusneoformans. Revista Ceuma Perspectivas, Ceuma. 30(1): 66-74.

Araújo, J.A.M., and Costa, E.M.C. Compostos derivados de nim (Azadirachta indica A. Juss) no controle de agentes fitopatogênicos. In.: Oliveira, V.R., Nogueira, N.W., Freitas, R.M.O., Costa, E. M., and Araújo, J.A.M. (Eds.). Nim (Azadirachta indica A. Juss): Aspectos gerais da propagação, cultivo e usos no controle de insetos-praga e doenças. Offset Editora, 1. ed, p.68, 2013.

Baldissera, M.D., Silva, A.S., Oliveira, C.B., Santos, R.C.V.,Vaucher, R.A.,Raffin, R. P., Gomes, P., Dambros, M.G.C., Milettie, L.C., Boligon, A.A., Athayde, M.L., and Monteiro, S.G. (2014). Trypanocidal action of tea tree oil (Melaleuca alternifolia) against Trypanosoma evansi in vitro and in vivo used mice as experimental model. Experimental Parasitology. 141: 21-27.

Barboza, H.S. (2015). Efeito fungitóxico do óleo essencial de alecrim-da-chapada em Alternaria sp. 2015. 31fls. Trabalho de Conclusão de Curso (Graduação em
Agronomia) - Universidade Federal do Semi-Árido, Mossoró. 2015.

Bastos, C.N. (1997). Efeito do óleo de Piper aduncumsobre Crinipelisperniciosae outros fungos fitopatogênicos. Fitopatologia Brasileira. 2(3):441-443.

Bester, W., Crous, P., and Fourie, P. (2007). Evaluation of fungicides as potential grapevine pruning wound protectants against Botryosphaeria species. Australasian Plant Pathology. 36(1):7377.

Caldefie-Chezet, F., Fusillier, C., Jarde, T., Laroye, H., Damez, M., Vasson, M. P., and Guillot, J. (2006). Potential antiinflammatory effects of Melaleuca alternifolia essential oil on human peripheral blood leukocytes. Phytotherapy Research. 20: 364.

Carson, C.F., Hammer, K., and Riley, T.V. (2006). Melaleuca alternifolia (Tea Tree) Oil: Areview of antimicrobial and other medicinal properties. Clinical Microbiology Reviews. 19(1): 50-62.

Conab - Companhia Nacional DE Abastecimento. (2018). Acompanhamento da safra brasileira de grãos -Safra 2017/18 - Nono levantamento, Brasília. 6(9): 1-178.

Concha, J.M., Moore, L.S., and Holloway, W.J. (1998). Antifungal activity of Melaleuca alternifolia (Tea-tree) oil against various pathogenic organisms. Journal. American Podiatric Medical Association. 88(10): 489-492.

Cox, S.D. et al., (2000). The mode of antimicrobial action of the essential oil Melaleuca alternifolia (tea tree oil). Journal of Applied Microbiology. 88: 170-175, 2000.

D'Auria, F.D., et al., (2001). In vitro activity of tea tree oil against Candida albicans mycelial conversion and other pathogenic fungi. Journal of Chemotherapy. 13: 377-383.

EMBRAPA. (1980). Doenças do milho. 
Brasília, DF: Embrapa Informação Agropecuária. 6(72): 50-53.

Fancelli, A.L., and Dourado Neto, D. (2008). Produção de milho. Guaíba: Agropecuária. 2: 1-360.

Feng, W., and Zheng, X. (2007). Essential oils to control Alternaria alternate in vitro and in vivo. Food Control.18:1261130.

Hammer, K.A., Carson, C.F., and Riley, T.V. (2004). Antifungal effects of Melaleucaalternifolia (tea tree) oil and its components on Candida albicans, Candida glabrata and Saccharomyces cerevisiae. Journal of Antimicrobial Chemotherapy, 53: 1081-1085.

http://portal.anvisa.gov.br/documents/111215/ 117782/M47-+Melaleuca+Alternifolia. pdf/82500eae-6881-4c13-8ae8-

$2 \mathrm{ab} 853 \mathrm{ac} 3 \mathrm{~d} 49$.

IBGE - Instituto Brasileiro de Geografia e Estatística (2005). Perdas de grãos, no Brasil, chegam a cerca de $10 \%$ da colheita, 2005. Acessed: 25 Sep 2018. Avaible:

https://agenciadenoticias.ibge.gov.br/ag encia-sala-de-imprensa/2013-agenciade-noticias/releases/12911-asi-perdasde-graos-no-brasil-chegam-a-cerca-de10-da-colheita.

Kalagatur, N.K., et al., (2018). Antifungal activity of chitosan nanoparticles encapsulated with Cymbopogon martini essential oil on plant pathogenic fungi Fusarium graminearum. Frontiers in Pharmacology. 9: 1-13.

Limonard, T. (1966). A modified blotter test for seed health. Netherland Journal of Plant Pathology, Wageningen. 72(2): 319-321.

Lis-Balchin, M., Hart, S., and Deans, S. G. (2000). Pharmacological and Antimicrobial Studies on Different Tea Tree Oils (M. alternifolia, $L$. scoparium or Manuka and K.ericioides or Kanuka),Originating in Australia and
New Zealand. Phytotherapy Research, v.14, p. 623.

Ma, H.X., Zhang, H.J., Shi, J., Dang, J.J., Chang, Y., Chen, D., Hu, Q.Y., Guo, N., and Han, H.L. (2016). First report of Lasiodiplodia theobromae causing maize ear rot in Hainan Province in Southern China. PlantDisease. 100(10): 2160.

MAPA - Ministério da Agricultura, Pecuária e Abastecimento (2009). - Registro sob o $\mathrm{n}^{\circ}$ 001193, 2009. Accessed: 13 Nov 2018. Available: <http://www. agricultura.gov.br>.

Marinelli, E. et al., (2012). Activity of some essential oils against pathogenic seed borne fungi on legumes. Asian Journal of Plant Pathology. 6: 66-74.

Martins, J.A.S., Sagata, E., Santos, V.A. and Juliatti, F.C. (2010). Avaliação do efeito do óleo de Melaleuca alternifolia sobre o crescimento micelial in vitro de fungos fitopatogênicos. Bioscience Journal. 27(1): 49-51.

Médice, R., Alves, E., Assis, R. T., Júnior, R. G. M., and Lopes, E.A.G.L. (2007) Óleos essenciais no controle da ferrugem asiática da sojaPhakopsorapachyrhiziSyd, \& P. Syd. Ciência Agrotecnológica. 31(1): 83-90.

Mikus, J., Harkenthal, M., Steverding, D., and Reichling, J. (2000). In vitro effect of essential oils and isolated mono and sesquiterpenes on Leishmania major and Trypanosoma brucei. Planta Medica. 66: 366-368.

Miranda, A.A.C., Melo, L.F., and Araújo, A.E. (2017). Impactos dos agrotóxicos na saúde do solo e humana: uma revisão. In: II Congresso Internacional das Ciencias Agrarias- COINTER, PDV Agro.

Nardelli, A. et al., (2009). Allergic contact dermatitis from fragrance components in specific topical pharmaceutical 
products in Belgium. Contact Dermatitis. 60: 303-313.

Nascimento, D.M. (2017). Efeito do tratamento de sementes de pimentão com óleos essenciais sobre o controle de Colletotrichumgloeosporioidese o potencial fisiológico das sementes. Dissertação (Mestrado em Proteção de Plantas) - Faculdade de Ciências Agronômicas, Universidade Estadual Paulista- UNESP. Botucatu, 2017.

Oliveira, J.A. (1991). Efeito do tratamento fungicida em sementes no controle de tombamento de plântulas de pepino (Cucumis sativas L.) e pimentão (Capsicum annum L.). 1991. 111 f. Dissertação (Mestrado em Fitossanidade) - Escola Superior de Agricultura de Lavras, Lavras, 1991.

Oliveira, M.Z.A.; Prates Júnior, P.; Assmar, C. C.; Barbosa, C. J. (2013). Fungo Lasiodiplodia theobromae: um problema para a agricultura baiana. Revista Bahia Agricola. 9: 24- 29.

Peixinho, G.S., Ribeiro, V.G., and Amorim, E.P.R. (2017a). Ação do óleo essencial de menta (Mentha arvensis) sobre o patógeno Lasiodiplodia theobromaeem cachos de videira cv. Itália. Summa Phytopathologica. 43(1): 32-35.

Peixinho, G.S., Ribeiro, V.G., and Amorim, E.P.R. (2017b). Controle da Podridão seca (Lasiodiplodia theobromae) em cachos de videira cv. Itália por óleos essenciais e quitosana. Summa Phytopathologica. 43(1):26-31.

Pereira, R.B., Alves, E., Ribeiro Júnior, P.M., Resende, M.L.V, Lucas, G.C., and Ferreira, J.B. (2008). Extrato de casca de café, óleo essencial de tomilho e acibenzolar-S-metil no manejo da cercosporiose-do-cafeeiro. Pesquisa Agropecuária Brasileira. 43: 12871296.

Pinto, N.F.J.A. (1998). Patologia de sementes de milho. Circular Técnica 29,
Ministério da Agricultura, Pecuária e Abastecimento, Sete Lagoas-MG, p. 44, 1998.

Ramos, D.P., Barbosa, R.M., Vieira, B.G.T.L., Panizzi, R.C., and Vieira, R.D. (2014). Infecção por Fusarium graminearum e Fusariumverticillioides em sementes de milho. Pesquisa Agropecuária Tropical. 44(1):24-31.

Ramos, K., Andreani Junior, R., andKozusnyAndreani, D.I. (2016). Óleos essenciais e vegetais no controle in vitro Colletotrichum gloeosporioides. Revista Brasileira de Plantas Medicinais.18(2):605-612.

Rodrigues, E. A. et al., (2006). Potencial da planta medicinal Ocimumgratissimum no controle de Bipolarissorokiniana em sementes de trigo. Acta Scientiarum Agronomy. 28:213-220.

Rolshausen, P.E.,Úrbez-Torres, J.R., RooneyLatham, S.,Eskalen, A., Smith, R.J., and Gubler, W. D. (2010). Evaluation of pruning wound susceptibility and protection against fungi associated with grapevine trunk diseases. American Journal of Enology and Viticulture. 61(1):113-119.

Silva, D.M.M.H., and Bastos, C. N. (2007).Atividade Antifúngica de Óleos Essenciais de espécies de Pipersobre Crinipellis perniciosa, Phytophthora palmivorae Phytophthora capsici. Fitopatologia Brasileira. 32:143-145.

Silva, J.C., Silva, A.A.S., and Assis, R.T. (2013). Sustentabilidade produtiva e inovação no campo Uberlândia: Composer. 1: 1-234.

Simões, R. P. (2002). Efeito do óleo de Melaleuca alternifolia sobre a infecção estafilocócica. Revista Lecta. Bragança Paulista. 20 (2): 143-152.

Souza, A.D.,Roggerio, T.U., Furlan, M.R.., andAoyama, E.M. (2015). Óleo de melaleuca (Melaleuca alternifolia Maiden \& Betche, Cheel) no controle 
decercosporiose em beterraba. Revista Brasileira Plantas Medicinais. 17(4):1078-1082.

Souza, C.N., and Fernandes, P.R. (2006). Avaliação do poder antimicrobiano do óleo de melaleuca e da planta Vernonias corpioides em alveolite induzida em ratos. Trabalho de Conclusão de Curso - Universidade do Vale do Itajaí. Itajaí, 2006.

Takahashi, J.P., andMelhem, M.S.C. (2014). Uso de fungicidas na agricultura e resistência a antifúngicos na clínica médica. Boletim do Instituto Adolfo Lutz. 1: 40-41.

United States Department of Agriculture USDA. Production, Supply and Distribution (PSD) on line. Accessed: 28 Nov 2018. Available: https://apps.fas.usda.gov/psdonline/app/ index.html\#/app/advQuery.

Venturoso, L. R. et al., (2011). Inibição do crescimento in vitro de fitopatógenos sob diferentes concentrações de extratos de plantas medicinais. Arquivos do Instituto Biológico, São Paulo.
78(1):89-95.

Venturoso, L.R.,Bacchi, L.M.A.,Gavassoni, W.L., Conus, L.A., Pontim, B.C.A., and Bergamin, A.C. (2011). Atividade antifúngica de extratos vegetais sobre o desenvolvimento de fitopatógenos. Summa Phytopatologica. 37(1):18-23.

Vigan, M. (2010). Essential oils: Renewal of interest and toxicity, European Journal of Dermatology.20(6):685-692.

Wardle, D.A., and Parkinson, D. (1990). Effects of three herbicides on soil microbial biomass and activity. Plant and Soil. 122: 21-28.

Wordell Filho, J.A. and Casa, R.T. (2010).Doenças na cultura do milho. In. Wordell Filho, J.A.and Elias, H.T. (Org.). A cultura do milho em Santa Catarina. lorianópolis, SC, Epagri,p. 207-273.

Yu, D., Wang, J., Shao, X., Xu, F., and Wang, H. (2015). Antifungal modes of action of tea tree oil and its two characteristic components against Botrytis cinerea. Journal of Applied Microbiology. 119: 1253-1262.

\section{How to cite this article:}

Ionaly Gomes de Araújo, Kevison Romulo da Silva Franca, Flavia Mota de Figueredo Alves, Alda Leaby dos Santos Xavier, Tiago Silva Lima, Lídia Pinheiro da Nóbrega, Antônio Francisco de Mendonça Júnior, Ana Paula Medeiros dos Santos Rodrigues and Tiago Augusto Lima Cardoso. 2019. Antifungal Activity of Melaleuca Essential Oil Against Lasiodiplodia theobromae in Maize Seeds. Int.J.Curr.Microbiol.App.Sci. 8(08): 1736-1746.

doi: https://doi.org/10.20546/ijcmas.2019.808.205 